\title{
Cold firn in the Mont Blanc and Monte Rosa areas, European Alps: spatial distribution and statistical models
}

\author{
Stephan SUTER, ${ }^{*}$ Martin HOELZLE ${ }^{\dagger}$ \\ Versuchsanstalt für Wasserbau, Hydrologie und Glaziologie, Eidgenössische Technische Hochschule, ETH-Zentrum, CH-8092 Zürich, Switzerland \\ E-mail: stephan.suter@meteoswiss.ch
}

\begin{abstract}
Near-surface firn temperatures were measured in 22 steam-drilled boreholes in the summit region of Mont Blanc (France and Italy) at 3800-4800 m a.s.l. in June 1998 and in 31 boreholes in the Monte Rosa area (Italy and Switzerland) at 3900$4500 \mathrm{~m}$ a.s.l. in May-July 1999. Borehole temperatures were logged to $22 \mathrm{~m}$ depth. The temperatures at $18 \mathrm{~m}$ depth ranged between temperate conditions and approximately $-15^{\circ} \mathrm{C}$. In a small altitude band, the observed distribution pattern suggests a strong influence of shortwave radiation and turbulent heat exchange (being generally more effective at wind-exposed sites). These two energy fluxes mainly determine the melt-energy input into the snow and firn during summer and, thereby, the measured near-surface temperatures. A statistical analysis of the measured firn temperatures revealed altitude-dependent firn temperature gradients of -1.48 and of $-2.36^{\circ} \mathrm{C}(100 \mathrm{~m})^{-1}$ for the Mont Blanc and Monte Rosa areas, respectively. The high lapse rates, as compared to the air-temperature lapse rate, are the result of englacial latent-heat contribution. The parameters elevation, potential direct solar radiation, slope and accumulation explain $>80 \%$ of the variation of the mean annual firn temperatures. Aspect-dependent lower boundaries for the coldfirn occurrence in the two areas ranged between 3500 and $4100 \mathrm{~m}$ a.s.l.
\end{abstract}

\section{INTRODUGTION}

Cold glaciers are a unique archive for climate and environmental studies. Near-absence of melt guarantees a continuous record of the climate and environmental history in the firn and ice. In contrast to the polar regions of Greenland and Antarctica, relatively little is known about the spatial distribution of negative firn temperatures in the European Alps and many other mountain ranges. Knowledge of the relevant atmospheric and englacial processes leading to the formation of cold firn is crucial for finding representative Alpine coredrilling sites and for assessing possible thermal consequences for these sites in view of a potential climate change.

In order to quantify firn and ice temperatures a mean annual firn temperature (MAFT) can be defined. Seasonal surface temperature fluctuations are normally reflected within the uppermost 10-20 m of the firn. The MAFT is found at a depth where seasonal temperature fluctuations vanish or, in practice, where they are within the accuracy range of the measurement. In the recrystallization zone (Shumskii, 1964), the MAFT is very close to the observed surface or air temperature. In the recrystallization-infiltration and cold-firn zones (Shumskii, 1964), the MAFT is normally higher than

\footnotetext{
* Present address: MeteoSwiss, P.O. Box 514, CH-8044
} Zürich, Switzerland.

† Present address: Geographisches Institut, Universität Zürich-Irchel, Winterthurerstrasse 190, CH-8057 Zürich, Switzerland. observed surface and air temperatures due to release of latent heat within the upper snow and firn layers from penetrating and refreezing surface meltwater.

The MAFT is mainly a result of the energy and mass balance at the glacier surface. Important parameters affecting the MAFT are mean annual air temperature (MAAT), radiation flux, volume and seasonality of accumulation/ ablation, volume of penetrating and refreezing meltwater, topographic location (hollow or ridge) and wind effects (Alean and others, 1984; Suter and others, 2001). Some of these parameters are closely linked to each other (e.g. topography, wind effects and volume of snow deposition). Other parameters that may influence the near-surface thermal regime are glacier flow velocity, extension and characteristics of the catchment basin (e.g. snow avalanches), firn and ice deformation, ground heat flux and occurrence of crevassed zones (Suter and others, 2001).

For a long time it was assumed that glaciers in the Alps were generally temperate, although Vallot (1893, 1913) reported cold firn in the Mont Blanc massif as early as the turn of the 20th century. Discussion of cold firn and ice in the Alps was reanimated by investigations in the Monte Rosa area (Fisher, 1953, 1954, 1955, 1963) and in the Jungfrau area (Haeberli and Brentani, 1955). Haeberli (1976) and Lliboutry and others (1976) were among the first to systematically assess the distribution of cold firn and ice in the Alps. In the past, extensive firn- and ice-temperature measurements were predominantly carried out at locations of specific practical or scientific interest in connection with construction work (e.g. Haefeli and Brentani, 1955; Haeberli and others, 1979), glacier risk prevention (Lüthi and Funk, 1997) and high-alpine core drillings (e.g. Oeschger and others, 1978; Alean and others, 


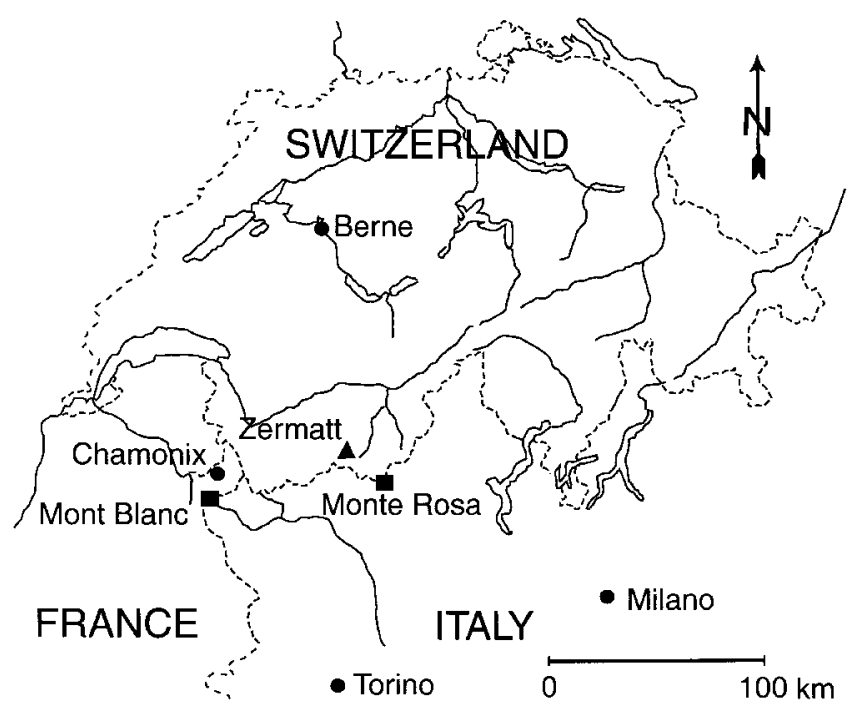

Fig. 1. Location of the Mont Blanc and Monte Rosa study areas.

1984; Haeberli and Funk, 1991; Vincent and others, 1997). A scheme for the spatial distribution of cold firn and ice was outlined by Hooke and others (1983) including near-surface temperatures of alpine and polar regions, and by Haeberli and Alean (1985) focusing on firn and ice temperatures from the Alps. Alean and others (1984) investigated interactions between snow deposition, firn temperature and solar radiation in the Colle Gnifetti (Monte Rosa) area. An altitudeand aspect-dependent statistical model of the distribution of cold firn and ice in accumulation areas of the Alps was developed by Suter and others (2001).

The goal of the present study was to systematically investigate the present-day spatial distribution of cold firn and its dependence on climatic and topographic variables in the Mont Blanc area, Western Alps (France and Italy), and in the Monte Rosa area, Southern Alps (Italy and Switzerland). Englacial temperature measurements were therefore made so as to

1. measure a mean annual firn temperature;

2. cover an altitude band as large as possible;

3. choose sites with varying climatic and topographic conditions;

4. detect an altitude-dependent boundary between cold and temperate firn, and

5. compare the present-day firn temperatures and cold-firn occurrence with earlier observations and models.

\section{FIELD OBSERVATIONS}

\section{Study areas}

The Mont Blanc study area $\left(45^{\circ} 50^{\prime} 30^{\prime \prime} \mathrm{N}, 6^{\circ} 51^{\prime} 00^{\prime \prime} \mathrm{E}\right.$; Figs 1 and 2) covers about $3 \mathrm{~km}^{2}$ and is located to the north of the Mont Blanc summit. It extends from about 3800 to $4800 \mathrm{~m}$ a.s.l. and comprises the accumulation areas of Glaciers de Bionnassay, de Taconnaz and des Bossons, as well as the summits of Mont Blanc (4807 ma.s.l.) and Dôme du Goûter (4304 $\mathrm{m}$ a.s.1.). The climate of the investigated area is characterized by almost constantly negative air temperatures and very high wind speeds since the massif is fully exposed to the (north)westerlies and, therefore, high precipitation rates. Due to generally high wind speeds, accumulation shows a large spatial variability from $0.2 \mathrm{~m} \mathrm{a}^{-1}$ w.e. at very windexposed sites (personal communication from S. Preunkert, 2001) to $4 \mathrm{~m} \mathrm{a}^{-1}$ w.e. at wind-protected sites (Vincent and others, 1997). Observed firn and ice depths range from a few

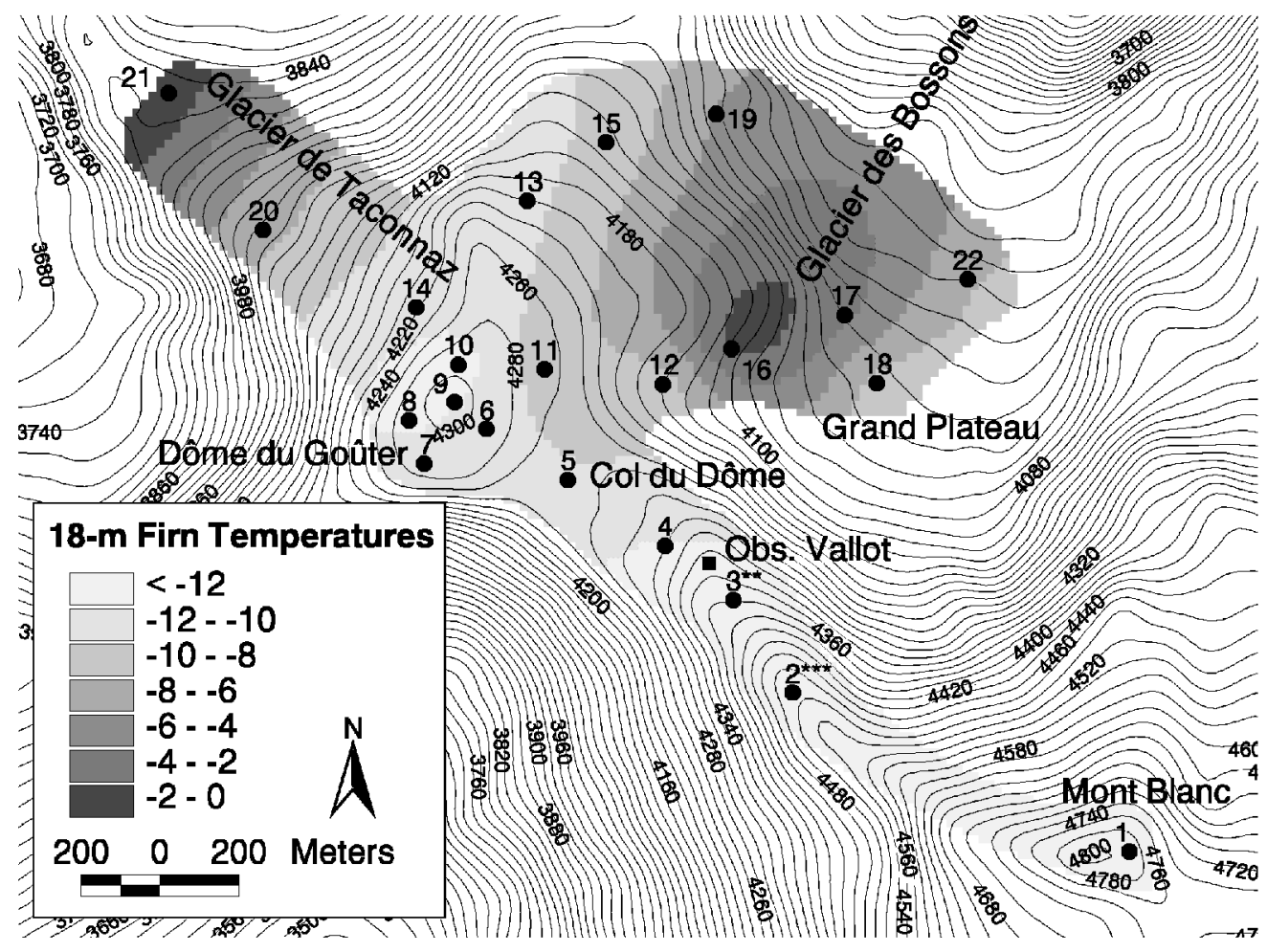

Fig. 2. Borehole locations and observed $18 \mathrm{~m}$ temperatures $\left({ }^{\circ} \mathrm{C}\right)$ in the Mont Blanc area, 1998, showing grid-interpolated values using a spline interpolation algorithm. ${ }^{* *}$ denotes a location with a value measured at $8 \mathrm{~m}$, and ${ }^{* * * *}$ with a value measured at $12 \mathrm{~m}$ depth. 
metres to about $40 \mathrm{~m}$ at exposed crests and domes, and from 120 to $>200 \mathrm{~m}$ at saddles and basins (Vincent and others, 1997; unpublished data).

The Monte Rosa study area $\left(45^{\circ} 55^{\prime} 20^{\prime \prime} \mathrm{N}, 7^{\circ} 52^{\prime} 00^{\prime \prime} \mathrm{E}\right.$; Figs 1 and 3) is about $4 \mathrm{~km}^{2}$ and covers the accumulation areas of the eastern part of Ghiacciaio del Lys and of Grenzgletscher above approximately $3900 \mathrm{~m}$ a.s.l. The climate in the study area is characterized by high-altitude conditions, i.e. practically persistent sub-zero air temperatures throughout the year, relatively high precipitation rates and high wind speeds. Snow accumulation is strongly variable, ranging from $0.3 \mathrm{ma}^{-1}$ w.e. at wind-exposed saddles and ridges to $2-3 \mathrm{~m} \mathrm{a}^{-1}$ w.e. at wind-protected sites (Gäggeler and others, 1983; Haeberli and others, 1983; Alean and others, 1984; Eichler and others, 2000). Observed ice depths in the study area range from 40 to $120 \mathrm{~m}$ at wind-exposed crests and saddles and from 80 to $>200 \mathrm{~m}$ in the central part of the firn basins (Haeberli and others, 1988; personal communication from D. S. Vonder Mühll, 1995; personal communication from G. C. Rossi, 2001).

\section{Methodology}

Firn temperatures were measured in steam-drilled and airfilled boreholes to a maximum depth of $22 \mathrm{~m}$ to ensure the detection of a MAFT. At borehole 0 (Fig. 3), firn temperatures were recorded at a permanently installed thermistor chain to $30 \mathrm{~m}$ depth. In all other boreholes, thermistor chains were removed after each measurement.

NTG thermistors incorporated in three different $30 \mathrm{~m}$ long thermistor chains with a $2 \mathrm{~m}$ sensor interval were used to measure a complete temperature profile. Data were recorded on three external data-logging systems applying a four-wire full bridge measurement on the thermistors. Each thermistor chain together with the logging unit was carefully calibrated at several temperatures between $0^{\circ}$ and $-18^{\circ} \mathrm{C}$ using a cold bath and a temperature-measuring device calibrated at the Swiss Federal Office of Metrology. The accuracy of the calibration is given by the stability of the cold bath, the resolution and accuracy of the data-logging unit, the characteristics of the thermistors and the cable and the absolute accuracy of the temperature-measuring device. The absolute accuracy of a thermistor measurement is $\pm 0.03^{\circ} \mathrm{C}$ at $0^{\circ}$ to $-10^{\circ} \mathrm{C}$ and $\pm 0.04^{\circ} \mathrm{C}$ at $-12.5^{\circ}$ to $-20^{\circ} \mathrm{C}$. The relative accuracy between the thermistors or of one and the same thermistor using the same measuring bridge is even better, $\pm 0.02^{\circ}$ and $\pm 0.01^{\circ} \mathrm{C}$, respectively.

After the steam-drilling operation, which lasted typically 60-90 min to a depth of $22 \mathrm{~m}$, the thermistor chain was installed from 12 hours to several days after drilling. Normally, no liquid water was found in the boreholes, and if it occurred, no measurements were made within the water column. After the thermistor chain was installed, the borehole was carefully sealed with isolating material at the surface to protect against snowdrift or immediate near-surface air movement in the borehole due to air-pressure fluctuations at high wind speeds. This procedure could not completely prevent rare in-borehole temperature fluctuations due to wind pumping. A convection effect in the air-filled boreholes with a maximum diameter of $6 \mathrm{~cm}$ can be excluded (Zotikov, 1986). Measurements were made for 12-24 hours at a 10-15 min sampling rate.

Measured resistances were converted into temperatures using the Steinhart-Hart equation

$$
\frac{1}{T}=a+b \ln R_{T}+c \ln ^{3} R_{T},
$$

where $T$ is the temperature $(\mathrm{K}), R_{T}$ is the resistance $(\Omega)$ and $a, b$ and $c$ are calibration coefficients. During the cali-

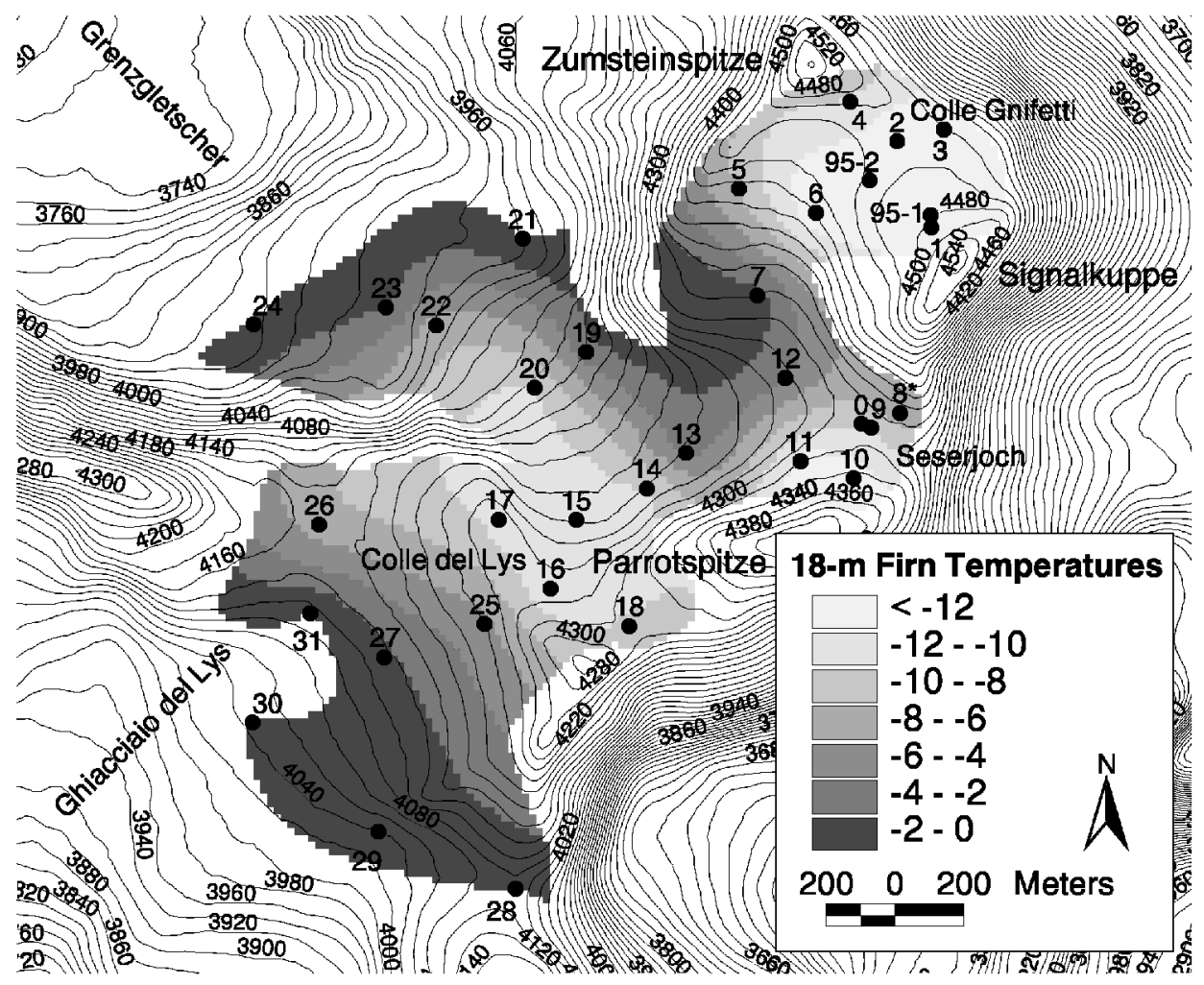

Fig. 3. Borehole locations and observed $18 \mathrm{~m}$ temperatures $\left({ }^{\circ} \mathrm{C}\right)$ in the Monte Rosa area, 1996 and 1999, showing grid-interpolated values using a spline interpolation algorithm. The two values from 1996 (boreholes 95-1 and 95-2) are taken from Lüthi (1999). * denotes a location with a value measured at $16 \mathrm{~m}$ depth. 
bration procedure, resistances were measured at three or more reference temperatures, and coefficients determined for each thermistor, individually.

Steam drilling into cold firn or ice disturbs the temperature distribution around the borehole. Therefore, a certain amount of time must elapse until temperatures have adjusted to the previously undisturbed conditions. The time for complete adjustment within a measuring accuracy of $0.1^{\circ} \mathrm{C}$ is on the order of a few days up to about 2 weeks (Laternser, 1992). Thus, extrapolation of continuous readings right after drilling is an easier and quicker way to obtain final (undisturbed) temperatures. This procedure was applied to all temperature measurements in steam-drilled boreholes with no permanent installation of a thermistor chain. Temperature $T$, at time $t$ after drilling, is

$$
T(t)=\frac{Q}{4 \pi K} \frac{1}{t}+T_{\mathrm{f}}
$$

(Lachenbruch and Brewer, 1959), where $Q$ is the energy input per unit length, $K$ is the thermal conductivity of firn and $T_{\mathrm{f}}$ is the undisturbed temperature or final temperature. Thus, $T(t)$ is proportional to $1 / t$ and $T_{\mathrm{f}}$ is the shift on the temperature axis found at $1 / t \approx 0$ for $t \rightarrow \infty$. No differences within the accuracy of the measurements could be found for the extrapolated final temperatures when using more sophisticated extrapolation formulae (Lachenbruch and Brewer, 1959) including the duration of the thermal disturbance (cf. Laternser, 1992; Suter, 1995). After insertion of the thermistor chain into the borehole, two effects of adjustment can be observed:

1. thermal inertia of the thermistor when adjusting to the ambient temperature, and

2. recording of the decrease in thermal perturbation caused by steam drilling.

At the beginning of the measurement these two effects cannot be separated. Thermal inertia of the thermistor when adjusting to the ambient temperature can be expressed by the following exponential relation:

$$
T(t)=T_{\mathrm{f}}+\left(T_{\mathrm{b}}-T_{\mathrm{f}}\right) \mathrm{e}^{-t / \tau},
$$

where $T(t)$ is the temperature at time $t, T_{\mathrm{f}}$ is the final temperature, $T_{\mathrm{b}}$ is the starting temperature and $\tau$ is the time constant. The time constant $\tau$ is a measure for the thermal inertia of a sensor and defined as the time until the sensor has adjusted to the final temperature to within $1 / \mathrm{e}$ of the total temperature change. In the case of thermistors, $\tau$ is mainly a function of the thermal insulation of the thermistor from surrounding conditions and the medium in which temperature is measured. $\tau$ was determined experimentally in the field by measuring in thermally undisturbed boreholes and typically found to be $11-31 \mathrm{~min}$. Measurements under nearly ideal conditions (practically no wind) showed that thermal adjustment to the ambient conditions was reached after $4-5$ hours at the latest after inserting the thermistor chain. The relatively large thermal inertia of the sensors is due to their wrapping in thermally isolating material and the low thermal conductivity $\left(0.025 \mathrm{~W} \mathrm{~m}^{-1} \mathrm{~K}^{-1}\right)$ of the surrounding (still) air. Thus, for the linear extrapolation procedure, the first 5 hours of data after inserting the thermistor chain into the borehole were generally omitted to avoid any effect of thermal sensor inertia. Since in extreme cases a perfect thermal adjustment of the thermistors was only reached after 9 hours, extrapolation was made using five datasets where the first 5, 6, 7, 8 or 9 hours were omitted, respectively. The final temperature was taken from the best linear relation (highest correlation coefficient) of these five sets. Below $10 \mathrm{~m}$ depth, differences between the five sets were generally small and typically $<0.01^{\circ} \mathrm{C}$. When temperatures were measured in thermally undisturbed boreholes, the first $3-5$ hours of data were omitted and a mean value obtained from stable conditions. Repeated measurements in the same borehole under disturbed and undisturbed conditions were made for one borehole in the Mont Blanc area (borehole 6; Fig. 2) and for two in the Monte Rosa area (boreholes 21 and 24; Fig. 3). Measurements were repeated after 1.5 and 6 weeks, respectively. Below $10 \mathrm{~m}$ depth (where a short-term variation due to seasonal temperature changes can be excluded for the period under consideration), maximum differences found between extrapolated and undisturbed values were $0.12^{\circ}$ (Monte Rosa) to $0.15^{\circ} \mathrm{C}$ (Mont Blanc). Since quite a strong wind pumping occurred during the "undisturbed" measurement in the Mont Blanc region, extrapolated temperatures may represent the undisturbed conditions with an accuracy better than $\pm 0.1^{\circ} \mathrm{C}$.

In this study, firn temperatures measured at $18 \mathrm{~m}$ depth (18 m temperature) were taken as MAFTs. Numerical calculations showed that under high accumulation rates a seasonal signal can penetrate down to $\sim 18 \mathrm{~m}$ depth. The time horizon which is resolved at $18 \mathrm{~m}$ depth is on the order of 2-3 years, practically independent of the accumulation rate (unpublished data).

\section{Firn temperatures}

The result of the observed $18 \mathrm{~m}$ temperatures in the 22 steamdrilled boreholes of the Mont Blanc area from June 1998 is shown in Figure 2. Temperatures were obtained using the linear extrapolation (boreholes 4-22; Equation (2)), an exponential extrapolation by plotting $\exp (T)$ vs $1 / t$ for measurements which could only be made for a few hours right after drilling (boreholes 1 and 2) or no extrapolation at all in thermally undisturbed conditions (borehole 3). The temperature measurements from boreholes 2 and 3 represent temperatures at 12 and $8 \mathrm{~m}$ depth, respectively. Due to refrozen meltwater in the boreholes after drilling into more or less massive ice, no temperature measurement was possible below these depths. Although temperatures were not measured at $18 \mathrm{~m}$ depth in these two boreholes, they were considered for further analysis as the observed temperature profiles in June were generally very close to a uniform temperature below $8 \mathrm{~m}$ depth. The $18 \mathrm{~m}$ temperature from borehole 6 is the mean between an extrapolated and a thermally undisturbed value. The measurements show a general trend to higher values with decreasing altitude. The "hot" spot found at $4100 \mathrm{~m}$ a.s.l. on Glacier des Bossons is the result of the high value $\left(-1.35^{\circ} \mathrm{C}\right)$ observed at borehole 16. No errors were detected during the measurement and data analysis, so the value is considered robust. The influence of a crevasse cannot be completely excluded, however. The relatively high value at the Mont Blanc summit is remarkable as compared to the observed firn temperatures at lower elevations and to earlier observations of $-16.5^{\circ} \mathrm{C}$ by Vallot (1893) and of $-20.2^{\circ} \mathrm{C}$ by Lliboutry and others (1976), although the latter measurement is very likely to be influenced by a crevasse. Compared to earlier measurements, a warming could be observed at Col du Dôme $\left(-12.8^{\circ} \mathrm{C}\right.$ in 1911 (Vallot (1913); $-10.3^{\circ} \mathrm{C}$ in 1998), whereas the value measured at Grand Plateau $\left(-8.6^{\circ} \mathrm{C}\right.$ in 1998) was similar to that in 1974 
$\left(-7.3^{\circ} \mathrm{C}\right.$; Lliboutry and others $\left.(1976)\right)$. The deep values at the foot of the Mont Blanc north face could be the result of coldsnow deposition due to avalanche activity. Temperate firn was found below about $3800 \mathrm{~m}$ a.s.l. on Glacier de Taconnaz, whereas the firn was still cold on the upper reaches of Glacier des Bossons at $3920 \mathrm{~m}$ a.s.l.

The $18 \mathrm{~m}$ temperatures measured in the 31 steam-drilled boreholes of the Monte Rosa area in May-July 1999 were generally obtained using the linear extrapolation procedure (Equation (2)). No extrapolation was made for boreholes where re-logging was done in July 1999 due to absent or erroneous measurements (boreholes 13, 16 and 18-24). At borehole 8 , a value could only be measured at $16 \mathrm{~m}$ depth due to refrozen meltwater in the borehole. The value from the permanently installed thermistor chain at borehole 0 is a daily mean value from 31 May 1999 and accumulation-corrected. The observed firn temperatures are shown in Figure 3. The $18 \mathrm{~m}$ temperatures follow a strong topographic pattern on Grenzgletscher, with deep values on shaded slopes, exposed firn saddles and crests. Surprisingly high values were found on the steep south slope beneath Colle Gnifetti, reaching almost $-1{ }^{\circ} \mathrm{C}$ and leading to extreme firn-temperature gradients within a short distance. A more altitude-dependent firntemperature distribution occurs on the gentle south slope of Ghiacciaio del Lys. The transition between cold and temperate firn occurred between approximately 3950 (Grenzgletscher) and $4050 \mathrm{~m}$ a.s.l. (Ghiacciaio del Lys). Compared to observations in the early 1990s (Suter and others, 2001), strongly increased MAFTs were observed on the steep south slope below Colle Gnifetti at 4250 ma.s.l. $\left(+1.7^{\circ} \mathrm{C}\right)$ and at $4300 \mathrm{~m}$ a.s.l. $\left(+4.9^{\circ} \mathrm{C}\right)$, whereas similar MAFTs were detected on Grenzgletscher below 4250 m a.s.l. in 1999.

\section{Accumulation}

Very bad weather conditions during the remainder of 1998 prevented the stakes set in the Mont Blanc area in June from being revisited, so no direct accumulation measurements were made. An accumulation index was used for the following statistical analysis distinguishing between weak (1), medium (2), heavy (3) and very heavy (4) accumulation as estimated from topography and (estimated) mean wind velocities.

In the Monte Rosa area, accumulation at borehole sites 1-24 was estimated using stake observations from May-July 1999 and snow-height measurements from an energybalance station at the Seserjoch (Fig. 3). For the extrapolation to an annual accumulation rate, we assumed that accumulation follows a regular spatial pattern over the year. Thus, the values observed from May to July 1999 at the above-mentioned sites were extrapolated taking a conversion factor derived as the ratio of the Seserjoch accumulations between 1 June 1999 and 31 May 2000 (2.1 m total accumulation) and between 1 June and 15 July 1999. No stake observations could be made for boreholes 11 and 19. The values for boreholes 4 and 95-2 were taken from Lüthi (1999) and for borehole 17 from a meteorological station at Colle del Lys (personal communication from G. C. Rossi, 2000; Fig. 3). No stake observations could be made for boreholes 25-31 on Ghiacciaio del Lys in 1999. Instead, annual accumulation rates from nearest stake points based on observations from September 1997 to August 1998 were considered (personal communication from G. G. Rossi, 2001) assuming precipitation conditions during this period similar to those
Table 1. Statistical results of the simple linear regression of the MAFTs vs elevation (ELEV) for the Mont Blanc (MB) and Monte Rosa (MR) areas

\begin{tabular}{cccccl}
\hline Area & $r$ & $r^{2}$ & Ftest & pvalue & Equation \\
\hline MB & -0.80 & 0.64 & 35.9 & $<0.001$ & MAFT $=52.7-0.0148 E L E V$ \\
MR -0.77 & 0.60 & 47.6 & $<0.001$ & MAFT $=92.4-0.0236 E L E V$ \\
\hline
\end{tabular}

during June 1999-May 2000. As in the Mont Blanc area, an accumulation index was derived for each borehole site.

\section{STATISTICAL ANALYSIS AND MODELS}

\section{Methodology}

The following simple and multiple linear regression calculations are based on the assumption that observations are independent and normally distributed and that residuals have uniform variances. Several statistical methods and tests were used to quantify the quality of the statistical validity: correlation coefficient $r$, coefficient of determination $r^{2}, F$ test and $p$ value.

A causal relation between the dependent variable MAFT and the independent variables elevation (ELEV), aspect (ASP), slope (SL), potential direct solar radiation (RAD), accumulation index (ACCI) and accumulation (ACC) was
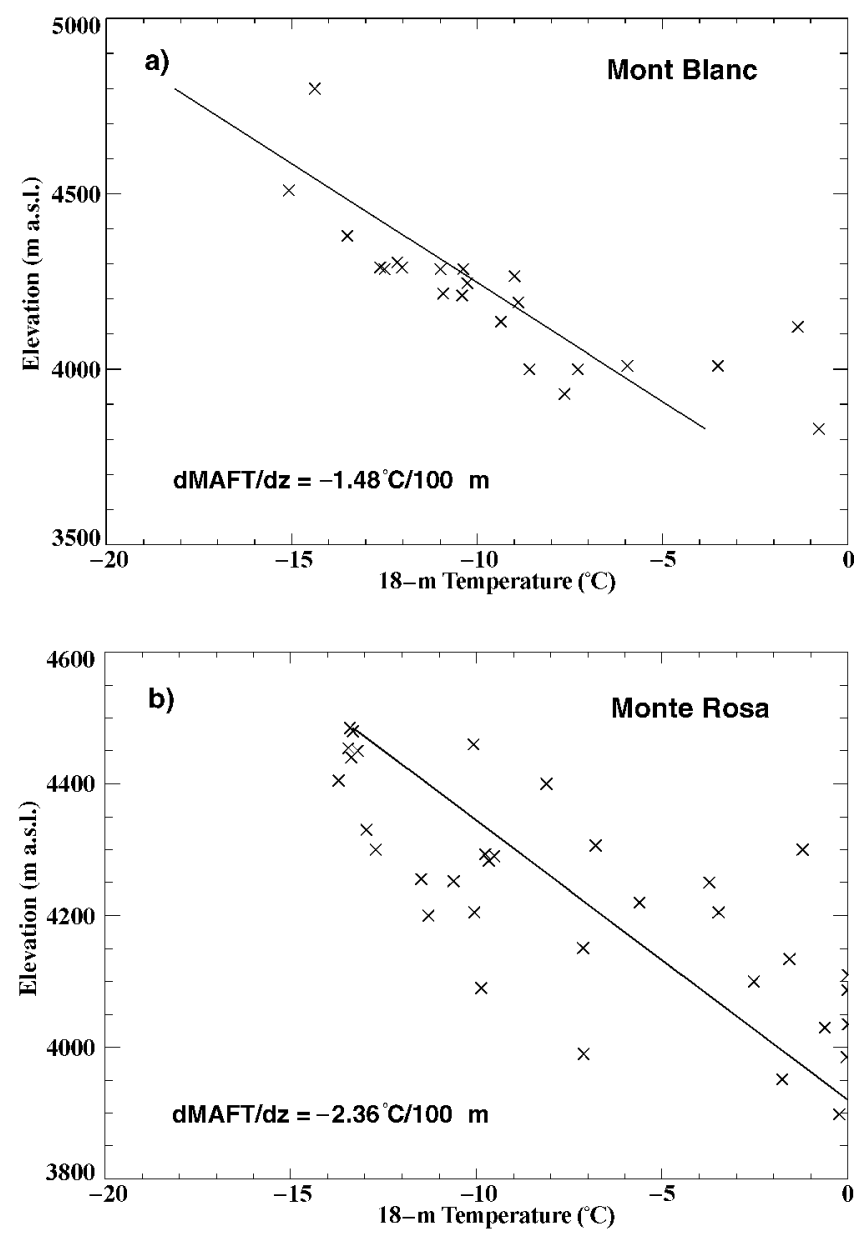

Fig. 4. Observed MAFTs from the Mont Blanc (a) and the Monte Rosa (b) areas as a function of elevation and calculated regression lines. 
Table 2. Statistical results of the multiple linear regression of the MAFTs vs elevation (ELEV), aspect (ASP), slope (SL), potential direct solar radiation ( $\mathrm{RAD}$ ), accumulation index ( $\mathrm{ACCI}$ ) and accumulation ( $\mathrm{ACC}$ ) for the Mont Blanc (MB) and Monte Rosa (MR) areas

\begin{tabular}{|c|c|c|c|c|c|}
\hline Area & $r$ & $r^{2}$ & F test & pvalue & Equation \\
\hline \multicolumn{6}{|c|}{ MAFT vs ELEV and ASP } \\
\hline MB & 0.85 & 0.73 & 22.5 & $<0.001$ & $\mathrm{MAFT}=54.8-0.0158 \mathrm{ELEV}+0.6337 \mathrm{ASP}$ \\
\hline MR & 0.90 & 0.81 & 50.7 & $<0.001$ & $\mathrm{MAFT}=80.1-0.0218 \mathrm{ELEV}+1.0081 \mathrm{ASP}$ \\
\hline \multicolumn{6}{|c|}{ MAFT vs ELEV and RAD } \\
\hline MB & 0.81 & 0.65 & 17.6 & $<0.001$ & $\mathrm{MAFT}=53.8-0.0155 \mathrm{ELEV}+0.0080 \mathrm{RAD}$ \\
\hline MR & 0.90 & 0.82 & 47.6 & $<0.001$ & $\mathrm{MAFT}=94.8-0.0269 \mathrm{ELEV}+0.0419 \mathrm{RAD}$ \\
\hline \multicolumn{6}{|c|}{ MAFT vs ELEV and ACCI } \\
\hline MB & 0.86 & 0.73 & 26.3 & $<0.001$ & $\mathrm{MAFT}=17.5-0.0074 \mathrm{ELEV}+1.5822 \mathrm{ACCI}$ \\
\hline MR & 0.78 & 0.61 & 24.0 & $<0.001$ & $\mathrm{MAFT}=77.6-0.0205 \mathrm{ELEV}+0.6447 \mathrm{ACCI}$ \\
\hline \multicolumn{6}{|c|}{ MAFT vs ELEV and ACC } \\
\hline & 0.78 & 0.60 & 21.1 & $<0.001$ & $\mathrm{MAFT}=81.5-0.0212 \mathrm{ELEV}+0.4067 \mathrm{ACG}$ \\
\hline \multicolumn{6}{|c|}{ MAFT is ELEV, ASP and SL } \\
\hline MB & 0.85 & 0.73 & 14.5 & $<0.001$ & $\mathrm{MAFT}=52.3-0.0154 \mathrm{ELEV}+0.6213 \mathrm{ASP}+0.0488 \mathrm{SL}$ \\
\hline MR & 0.94 & 0.88 & 57.7 & $<0.001$ & $\mathrm{MAFT}=84.5-0.0219 \mathrm{ELEV}+1.0781 \mathrm{ASP}-0.2680 \mathrm{SL}$ \\
\hline \multicolumn{6}{|c|}{ MAFT vs ELEV, ASP and ACCI } \\
\hline MB & 0.89 & 0.79 & 20.3 & $<0.001$ & $\mathrm{MAFT}=23.4-0.0091 \mathrm{ELEV}+0.5480 \mathrm{ASP}+1.4322 \mathrm{ACCI}$ \\
\hline MR & 0.90 & 0.81 & 32.4 & $<0.001$ & $\mathrm{MAFT}=82.4-0.0223 \mathrm{ELEV}+1.0148 \mathrm{ASP}-0.0992 \mathrm{ACCI}$ \\
\hline \multicolumn{6}{|c|}{ MAFT us ELEV, RAD and ACCI } \\
\hline MB & 0.88 & 0.77 & 20.6 & $<0.001$ & $\mathrm{MAFT}=12.3-0.0074 \mathrm{ELEV}+0.0187 \mathrm{RAD}+1.9391 \mathrm{ACCI}$ \\
\hline MR & 0.91 & 0.82 & 46.8 & $<0.001$ & $\mathrm{MAFT}=81.7-0.0242 \mathrm{ELEV}+0.0418 \mathrm{RAD}+0.5673 \mathrm{ACCI}$ \\
\hline \multicolumn{6}{|c|}{ MAFT vs ELEV, RAD and ACC } \\
\hline MR & 0.91 & 0.84 & 45.6 & $<0.001$ & $\mathrm{MAFT}=94.7-0.0271 \mathrm{ELEV}+0.0460 \mathrm{RAD}-0.0415 \mathrm{ACC}$ \\
\hline \multicolumn{6}{|c|}{ MAFT us ELEV, ASP, SL and ACCI } \\
\hline MB & 0.89 & 0.79 & 14.4 & $<0.001$ & $\mathrm{MAFT}=22.8-0.0091 \mathrm{ELEV}+0.5439 \mathrm{ASP}+0.0230 \mathrm{SL}+1.4031 \mathrm{ACCI}$ \\
\hline MR & 0.94 & 0.89 & 43.3 & $<0.001$ & $\mathrm{MAFT}=70.8-0.0190 \mathrm{ELEV}+1.0432 \mathrm{ASP}-0.2879 \mathrm{SL}+0.5940 \mathrm{ACCI}$ \\
\hline \multicolumn{6}{|c|}{ MAFT vs ELEV, RAD, SL and ACCI } \\
\hline MB & 0.90 & 0.81 & 18.0 & $<0.001$ & $\mathrm{MAFT}=9.2-0.0079 \mathrm{ELEV}+0.0320 \mathrm{RAD}+0.1390 \mathrm{SL}+1.8093 \mathrm{ACCI}$ \\
\hline MR & 0.91 & 0.82 & 34.1 & $<0.001$ & $\mathrm{MAFT}=78.4-0.0234 \mathrm{ELEV}+0.0410 \mathrm{RAD}-0.0291 \mathrm{SL}+0.7249 \mathrm{ACCI}$ \\
\hline \multicolumn{6}{|c|}{ MAFT vs ELEV, RAD, SL and ACC } \\
\hline MR & 0.91 & 0.84 & 33.1 & $<0.001$ & $\mathrm{MAFT}=94.8-0.0271 \mathrm{ELEV}+0.0459 \mathrm{RAD}-0.0181 \mathrm{SL}-0.0088 \mathrm{ACC}$ \\
\hline
\end{tabular}

presumed. The statistical models are considered to be valid in the parameter space of the observations. They have a restricted validity for aspects in the range west-southwest-south-eastsoutheast (WSW-S-ESE) and potential direct solar radiation exceeding $350 \mathrm{~W} \mathrm{~m}^{-2}$ in the Mont Blanc study area, due to a limited number of measurements in these aspects.

\section{Further input data}

The regression analysis requires additional input data:

\section{Digital elevation models (DEMs)}

The DEM of the Mont Blanc study area is based on digitally analyzed aerial photographs of the Mont Blanc region from 1993 obtained from the Institut Géographique National in France and on manual correction based on the Swiss topographic map 1:50000.

The DEM of the Monte Rosa study area was compiled using digitized contour lines from the 1977 land registry plan 1:10000 for the Swiss part and merged with a DEM of the Italian Ghiacciaio del Lys based on aerial photographs from 1994 (personal communication from G. C. Rossi, 1999).

\section{Aspect and slope}

The topographic aspect and slope can be considered a good proxy parameter for incoming solar radiation in a moun- tain area, as can be seen below. Aspect and slope information were derived from the corresponding DEMs for each borehole or estimated from the map (aspect). A coding system was used for the aspect where north receives the smallest (1) and south the highest value (9). The aspects northwest and northeast (value 3), west and east (value 5) and southwest and southeast (value 7) were considered symmetrical. No aspect was attributed to sites with a slope $\leq 4^{\circ}$.

\section{Potential direct solar radiation}

Potential direct solar radiation is a good approximation of the shortwave incoming radiation, making an important contribution to the surface energy balance and its spatial and temporal variation (e.g. Funk, 1985). Using potential direct solar radiation as a proxy parameter for shortwave incoming radiation neglects the effect of spatial and temporal variations of cloud cover on the MAFTs. Due to a lack of observations, no statement can be made on the impact of cloud cover. It can, however, be assumed that its spatial variation is small within the study areas given their small extent. Potential direct solar radiation was calculated for each borehole site using the grid-based computer program SRAD (Moore and others, 1993a, b) and the DEM data. The program calculates the radiation total on a daily basis and considers, besides aspect and slope angle, topographic 
shading. Additionally, atmospheric scattering, reflection and absorption are taken into account. For the regression calculations a daily mean value averaged over 1 year was calculated. Values ranged between 175 and $405 \mathrm{~W} \mathrm{~m}^{-2}$ at the drill sites.

\section{Simple linear regression}

The regression of the observed $18 \mathrm{~m}$ temperatures or MAFTs against elevation (ELEV) can be written as

$$
\mathrm{MAFT}=a+b \mathrm{ELEV}+\epsilon,
$$

where $a$ is the intercept, $b$ is the slope and $\epsilon$ is the residual. Statistical results are given in Table 1. Figure 4 shows the observed MAFTs plotted against elevation. For the Mont Blanc area, $64 \%$ of the variation of the MAFTs can be explained by the elevation alone; $60 \%$ in the case of the Monte Rosa area. An altitude-dependent firn-temperature gradient of $-1.48^{\circ} \mathrm{C}(100 \mathrm{~m})^{-1}$ and of $-2.36^{\circ} \mathrm{C}(100 \mathrm{~m})^{-1}$ was calculated for the Mont Blanc and Monte Rosa areas, respectively. The calculated boundary between cold and temperate firn lies at $3570 \mathrm{~m}$ a.s.l. in the Mont Blanc and at $3920 \mathrm{~m}$ a.s.l. in the Monte Rosa area. The large discrepancy in gradients and lower boundary of cold-firn occurrence is due to the under-representation of southerly aspects in the Mont Blanc sample and the relatively high MAFT at the Mont Blanc summit and should not be interpreted climatologically. If the high MAFT at the Mont Blanc summit is omitted and only values in "cold" aspects (WNW-N-ENE) are regressed in both samples, gradients are $-1.90^{\circ} \mathrm{C}(100 \mathrm{~m})^{-1}$ for the Mont Blanc and $-2.14^{\circ} \mathrm{C}(100 \mathrm{~m})^{-1}$ for the Monte Rosa area. Compared to an earlier investigation (Suter and others, 2001), altitudedependent firn-temperature gradients are higher in the current datasets.

\section{Multiple linear regression}

The relation between the dependent variable MAFT and the independent variables elevation (ELEV), aspect (ASP), slope (SL), potential direct solar radiation (RAD), accumulation index (ACCI) and accumulation $(\mathrm{ACC})$ is given as

$$
\begin{aligned}
\mathrm{MAFT}=a & +b \mathrm{ELEV}+c \mathrm{ASP}+d \mathrm{SL}+e \mathrm{RAD} \\
& +f \mathrm{ACCI}+g \mathrm{ACC}+\epsilon,
\end{aligned}
$$

where $a$ is the intercept, $b, c, d, e, f$ and $g$ are coefficients and $\epsilon$ is the residual. The statistical results for several combinations of parameters are summarized in Table 2. All multiple linear regression models show high correlation coefficients, coefficients of determination and $F$-test values. All models are very strongly significant. Care must be taken for the Mont Blanc area, as southerly aspects are under-represented, which is critical when looking at aspect and radiation. This fact leads to generally better statistical results for the Monte Rosa area.

The easily determined parameters elevation and aspect are able to explain $73 \%$ and $81 \%$ of the MAFT variation in the Mont Blanc and Monte Rosa areas, respectively. For the Monte Rosa area an even better result is achieved when aspect is replaced by potential direct solar radiation $\left(r^{2}=\right.$ 0.82). This is not the case for the Mont Blanc area due to the radiation-exposed location of some very cold sites (Fig. 2). An equal (Mont Blanc) or improved (Monte Rosa) result is found when the regression is made with elevation, aspect and slope. The combination of aspect and slope gives a better proxy for radiation. In addition, slope can be considered a proxy for turbulent heat exchange which is generally more
Table 3. Lower boundary ( $m$ a.s.l.) of cold-firn occurrence as a function of aspect (ASP) for the Mont Blanc and Monte Rosa areas

\begin{tabular}{ccc}
\hline ASP & Mont Blanc & Monte Rosa \\
& & \\
\hline $\mathrm{N}$ & 3510 & 3720 \\
$\mathrm{NW} / \mathrm{NE}$ & 3590 & 3820 \\
$\mathrm{~W} / \mathrm{E}$ & 3670 & 3910 \\
$\mathrm{SW} / \mathrm{SE}$ & 3750 & 4000 \\
$\mathrm{~S}$ & 3830 & 4090 \\
\hline
\end{tabular}

effective in flatter terrain than on steep slopes. Elevation and accumulation alone do not sufficiently explain the $18 \mathrm{~m}$ temperature variation except for the Mont Blanc region where deep MAFTs coincide with a low accumulation index $\left(r^{2}=0.73\right)$. However, satisfying results are obtained when combining radiation or radiation proxy-parameters aspect and slope with accumulation. For the Mont Blanc area, the parameters elevation, aspect and accumulation index, or elevation, aspect, slope and accumulation index, are able to explain $79 \%$ of the MAFT variation. For the Monte Rosa area, the parameters elevation, aspect, slope and accumulation index explain 89\%. When combining altitude, radiative, heat-exchange (slope) and accumulation information, coefficients of determination of 0.81 (Mont Blanc) and 0.82-0.84 (Monte Rosa) are found.

\section{Lower boundaries of cold-firn occurrence}

Using the above statistical relationships, it is possible to derive spatial distribution models for cold firn based on the topographic and climatic parameters ELEV, ASP, SL, RAD and ACCI which are relatively easy to measure, estimate or calculate. The lower boundary of cold-firn occurrence is found where the MAFT becomes $0^{\circ} \mathrm{C}$ and can then be written as (cf. Equation (5))

$$
\mathrm{ELEV}_{\text {bound }}=-\frac{a+c \mathrm{ASP}+d \mathrm{SL}+e \mathrm{RAD}+f \mathrm{ACCI}}{b},
$$

where $\mathrm{ELEV}_{\text {bound }}$ is the lower boundary of the cold-firn distribution, $a$ is the intercept, $c, d, e$ and $f$ are coefficients and $b$ is the slope of the parameter elevation.

\section{$\mathrm{ELEV}_{\text {bound }}$ vs ASP}

The aspect-dependent lower boundaries of the two areas (Table 3) are quite similar and differ on the order of $230 \mathrm{~m}$. The discrepancy increases towards southerly aspects, perhaps due to a lack of observations in the Mont Blanc area.

Table 4. Lower boundary ( $m$ a.s.l.) of cold-firn occurrence as a function of potential direct solar radiation (RAD) for the Mont Blanc and Monte Rosa areas

\begin{tabular}{ccc}
\hline RAD & Mont Blanc & Monte Rosa \\
$\mathrm{W} \mathrm{m}^{-2}$ & & \\
\hline 200 & 3570 & 3840 \\
300 & 3630 & 3990 \\
400 & 3680 & 4150 \\
\hline
\end{tabular}


Table 5. Lower boundary ( $m$ a.s.l.) of cold-firn occurrence as a function of aspect (ASP) and slope (SL) for the Mont Blanc and Monte Rosa areas

\begin{tabular}{|c|c|c|c|c|c|c|}
\hline \multirow{3}{*}{ ASP } & \multicolumn{3}{|c|}{ Mont Blanc } & \multicolumn{3}{|c|}{ Monte Rosa } \\
\hline & & SL & & & SL & \\
\hline & 10 & & 30 & 10 & 20 & 30 \\
\hline $\mathrm{N}$ & 3480 & 3510 & 3540 & 3790 & 3660 & 3540 \\
\hline $\mathrm{NW} / \mathrm{NE}$ & 3560 & 3590 & 3620 & 3880 & 3760 & 3640 \\
\hline $\mathrm{W} / \mathrm{E}$ & 3640 & 3670 & 3700 & 3980 & 3860 & 3740 \\
\hline $\mathrm{SW} / \mathrm{SE}$ & 3720 & 3750 & 3780 & 4080 & 3960 & 3840 \\
\hline S & 3800 & 3830 & 3860 & 4180 & 4060 & 3940 \\
\hline
\end{tabular}

\section{ELEV $_{\text {bound }}$ vs RAD}

The radiation-dependent lower boundaries of the two areas show a slightly narrower range than the aspect-dependent values (Table 4). However, ranges are very similar.

$\mathrm{ELEV}_{\text {bound }}$ vs ASP and SL

When aspect and slope information are combined, lower boundaries rise for steeper terrain in Mont Blanc, whereas the opposite is observed for Monte Rosa (Table 5). This can be explained by some relatively deep values on steep and shady slopes in Monte Rosa. The ranges obtained are similar to the aspect-dependent lower boundaries, showing that the influence of slope alone is weak. The scatter is somewhat larger in the Monte Rosa than in the Mont Blanc area.

$\mathrm{ELEV}_{\text {bound }}$ vs ASP and ACCI

Incorporation of an accumulation index leads to a strong
Table 6. Lower boundary ( $m$ a.s.l.) of cold-firn occurrence as a function of aspect ( ASP) and accumulation index ( ACCI) for the Mont Blanc and Monte Rosa areas

\begin{tabular}{|c|c|c|c|c|c|c|c|c|}
\hline \multirow[t]{2}{*}{ ASP } & \multicolumn{4}{|c|}{$\begin{array}{c}\text { Mont Blanc } \\
\text { ACCI }\end{array}$} & \multicolumn{4}{|c|}{$\begin{array}{l}\text { Monte Rosa } \\
\text { ACCI }\end{array}$} \\
\hline & 1 & 2 & 3 & 4 & 1 & 2 & 3 & 4 \\
\hline $\mathrm{N}$ & 2770 & 2930 & 3090 & 3250 & 3740 & 3740 & 3730 & 3730 \\
\hline $\mathrm{NW} / \mathrm{NE}$ & 2890 & 3050 & 3210 & 3360 & 3830 & 3830 & 3830 & 3820 \\
\hline $\mathrm{W} / \mathrm{E}$ & 3010 & 3170 & 3330 & 3480 & 3930 & 3920 & 3920 & 3910 \\
\hline $\mathrm{SW} / \mathrm{SE}$ & 3130 & 3290 & 3450 & 3600 & 4020 & 4010 & 4010 & 4000 \\
\hline S & 3250 & 3410 & 3570 & 3720 & 4110 & 4100 & 4100 & 4090 \\
\hline
\end{tabular}

decrease in elevation of the $0^{\circ} \mathrm{C}$ firn-temperature line for the Mont Blanc area, whereas practically no influence can be seen for the Monte Rosa area (Table 6).

\section{$\mathrm{ELEV}_{\text {bound }}$ vs RAD and ACCI}

When aspect is replaced by calculated potential direct solar radiation, an even larger lowering of the lower boundary can be observed for the Mont Blanc area. A range of lower boundaries similar to that in Table 6 is found for Monte Rosa, showing elevated lower boundaries with increasing radiation and accumulation index (Table 7).

\section{Cold-firn distribution in the Zermatt region}

Based on the relation between the observed MAFTs in the Monte Rosa study area and the parameters elevation and aspect, a firn-temperature distribution for a larger area in

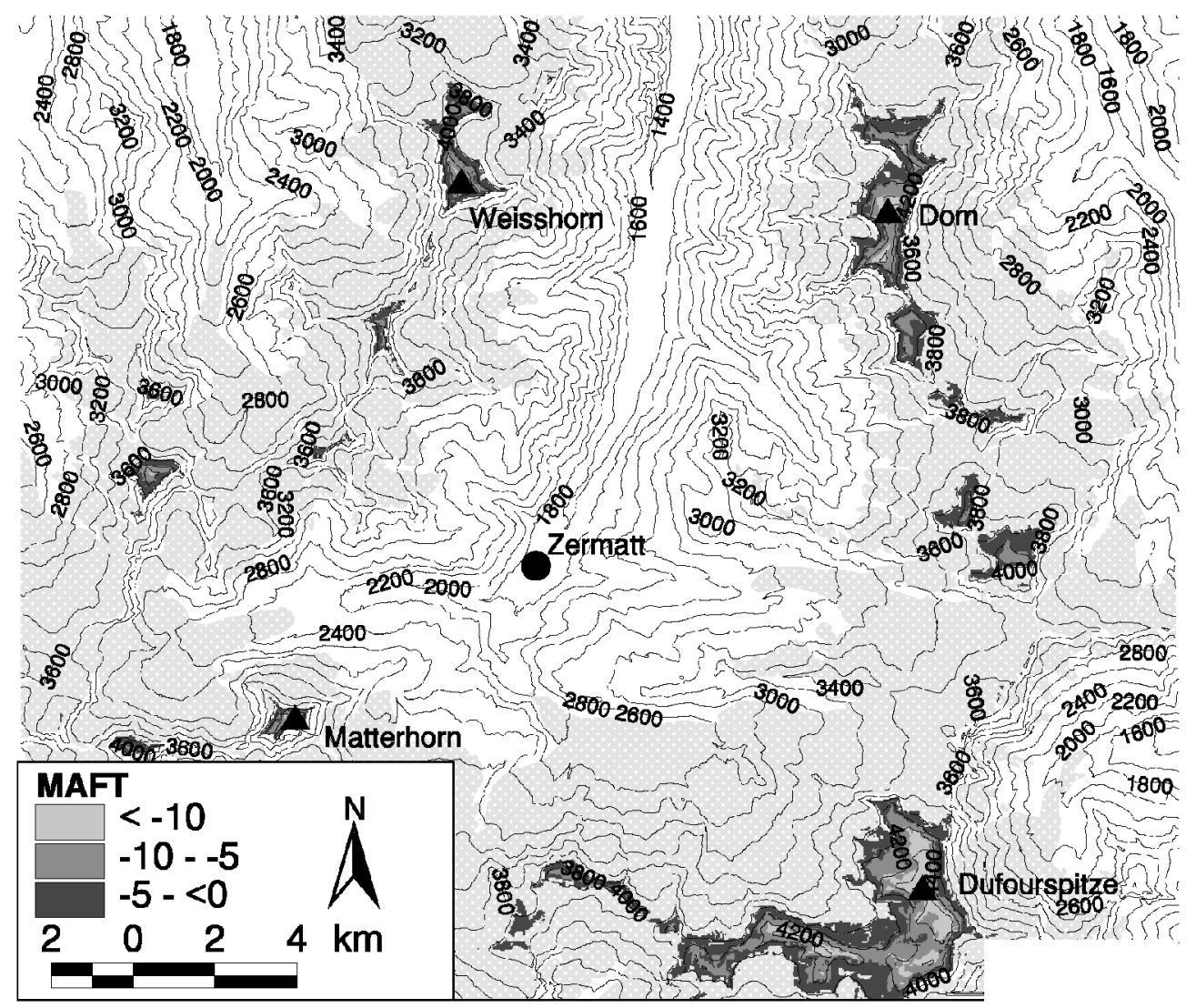

Fig. 5. Statistically simulated distribution of cold firn in the Zermatt region based on the parameters elevation and aspect. MAFTs are given in ${ }^{\circ}$ C. Light grey, white dotted areas represent glacier extent. ( Topographic data: DHM25 (C) Swiss Federal Office of Topography.) 
Table 7. Lower boundary ( $m$ a.s.l.) of cold-firn occurrence as a function of potential direct solar radiation (RAD) and accumulation index (ACCI) for the Mont Blanc and Monte Rosa areas

\begin{tabular}{cccccccccc}
\hline & \multicolumn{4}{c}{ Mont Blanc } & \multicolumn{5}{c}{ Monte Rosa } \\
RAD & \multicolumn{4}{c}{ ACCI } & \multicolumn{1}{c}{ ACCI } \\
& 1 & 2 & 3 & 4 & 1 & 2 & 3 & 4 \\
$\mathrm{~W} \mathrm{~m}^{-2}$ & & & & & & & & \\
& & & & & & & & \\
\hline \multirow{2}{*}{200} & 2420 & 2680 & 2940 & 3200 & 3750 & 3770 & 3790 & 3820 \\
300 & 2670 & 2930 & 3190 & 3450 & 3920 & 3940 & 3970 & 3990 \\
400 & 2920 & 3180 & 3440 & 3700 & 4090 & 4120 & 4140 & 4160 \\
& & & & & & & & & \\
\hline
\end{tabular}

the Zermatt region was computed (Figs 1 and 5). Such a distribution model should be able to explain $81 \%$ of the firntemperature variation (Table 2). The calculation was performed within ARC/INFO and ArcView based on a digital elevation model with a $25 \mathrm{~m}$ resolution (DHM25 (C) Swiss Federal Office of Topography). As compared to an earlier distribution model for the region (Suter and others, 2001), the present occurrence of cold firn is restricted to highelevation sites above approximately $3700 \mathrm{~m}$ a.s.l.

\section{GONGLUSIONS}

In the Mont Blanc as well as in the Monte Rosa area, MAFTs generally decrease with elevation. Wind-exposed saddles and crests show low temperatures, whereas relatively steep slopes with southerly aspects often have near-temperate conditions, which results in high to extreme firn-temperature variations within very short distances. Observations in the Monte Rosa area show a clearer dependence on aspect and potential direct solar radiation than those in the Mont Blanc area. The distribution pattern suggests a strong influence of shortwave radiation and turbulent heat exchange (being generally more efficient at wind-exposed sites). During the surface-melt period in summer, these two energy fluxes mainly determine the melt-energy input into the snow and firn, and thereby the near-surface temperatures found.

The parameter elevation explains $64 \%$ and $60 \%$ of the variation of the MAFTs in the Mont Blanc and Monte Rosa areas, respectively. Resulting high firn-temperature gradients (changes of MAFT with elevation) cannot be explained by the air-temperature lapse rate alone, but rather show a strong influence of latent-heat release for the near-surface thermal regime, and thereby a high spatial variation in microclimatic conditions. The climatic and topographic parameters elevation, aspect, slope, potential direct solar radiation, accumulation index and accumulation explain up to $81 \%$ and $89 \%$ of the MAFT variation in the Mont Blanc and Monte Rosa study areas, respectively. Lower boundaries of cold-firn occurrence were calculated for the two study areas based on aspect, slope, potential direct solar radiation and accumulation index. A plausible range of lower boundaries results for the Monte Rosa area and a more unrealistic pattern for the Mont Blanc area, especially if potential direct solar radiation is combined with accumulation. The representativity of the Mont Blanc dataset is questionable for southerly aspects, since measurements in these aspects are sparse. The effect of slope was unclear since steeper slopes showed a cooling effect in the Monte Rosa and a warming effect in the Mont Blanc area. The distribution of cold firn was modelled for the Zermatt region based on the statistical relationship between $18 \mathrm{~m}$ temperature from the Monte Rosa study area, elevation and aspect. Compared to an earlier distribution model based on elevation and aspect using a dataset of the Alps from 1950 to 1994 (Suter and others, 2001), cold firn now occurs at lower elevations on slopes with southerly aspects in Mont Blanc and at higher elevations on slopes with northerly aspects in the Monte Rosa area. The aspect-dependent range of the lower boundaries is less pronounced in the present study and is found at 300-400 m compared to $750 \mathrm{~m}$ in the earlier investigation. Some single sites in the Mont Blanc and Monte Rosa areas show a significant increase in MAFT since earlier investigations. The present-day distribution pattern of cold firn lies well within the boundaries of the previous distribution model based on elevation and aspect (Suter and others, 2001). Although lower boundaries of coldfirn occurrence are higher in northerly aspects and lower in southerly aspects than in the previous model, a major change in cold-firn occurrence cannot be inferred for the Alps over the last 50 years.

\section{ACKNOWLEDGEMENTS}

This research was supported by the European Union Environment and Climate Programme under contract No. ENV4-CT97-0639 and the Swiss Government under BBW Nr. 97.0349-1. We gratefully acknowledge many students and colleagues at the Section of Glaciology of the Laboratory of Hydraulics, Hydrology and Glaciology (VAW) at ETH Zürich, the Laboratoire de Glaciologie et Géophysique de l'Environnement, Grenoble, France, and the Institute of Geography at the University of Zürich for their help with the strenuous fieldwork at high altitude. We are especially indebted to G. C. Rossi for providing many useful data and to $\mathrm{P}$. Jansson and an anonymous reviewer for carefully reviewing the present paper.

\section{REFERENGES}

Alean, J., W. Haeberli and B. Schädler. 1984. Snow accumulation, firn temperature and solar radiation in the area of the Colle Gnifetti core drilling site (Monte Rosa, Swiss Alps): distribution patterns and interrelationships. Z. Gletscherkd. Glazialgeol., 19(2), 1983, 131-147.

Eichler, A. and 7 others. 2000. Glaciochemical dating of an ice core from upper Grenzgletscher (4200 m a.s.l.). F. Glaciol., 46(154), 507-515.

Fisher, J. E. 1953. The cold ice tunnel on the Silbersattel, Monte Rosa. F. Glaciol., 2(13), 195-196/193-194.

Fisher, J. E. 1954. The cold ice tunnel on the Silbersattel, Monte Rosa. 1953 progress. F. Glaciol., 2 (15), 341.

Fisher, J. E. 1955. Internal temperatures of a cold glacier and conclusions therefrom. 7. Glaciol., 2(18), 583-591/582.

Fisher, J. E. 1963. Two tunnels in cold ice at 4,000 $\mathrm{m}$ on the Breithorn. F. Glaciol., $4(35), 513-520$

Funk, M. 1985. Räumliche Verteilung der Massenbilanz auf dem Rhonegletscher und ihre Beziehung zu Klimaelementen. Zürcher Geogr. Schr. 24

Gäggeler, H., H. R. von Gunten, E. Rössler, H. Oeschger and U. Schotterer. 1983. ${ }^{210} \mathrm{~Pb}$-dating of cold Alpine firn/ice cores from Colle Gnifetti, Switzerland. F. Glaciol., 29(101), 165-177.

Haeberli, W. 1976. Eistemperaturen in den Alpen. Z. Gletscherkd. Glazialgeol., $11(2), 1975,203-220$.

Haeberli, W. and J. Alean. 1985. Temperature and accumulation of high altitude firn in the Alps. Ann. Glaciol., 6, 161-163.

Haeberli, W. and M. Funk. 1991. Borehole temperatures at the Colle Gnifetti core-drilling site (Monte Rosa, Swiss Alps). F. Glaciol., 37(125), 37-46.

Haeberli, W., A. Iken and H. Siegenthaler. 1979. Glaziologische Aspekte beim Bau der Fernmelde-Mehrzweckanlage der PTT auf dem Chli Titlis. Eidg. Tech. Hochschule, Zürich. Versuchsanst. Wasserbau, Hydrol. Glaziol. Mitt. 41, 59-75. 
Haeberli, W., U. Schotterer, D. Wagenbach, H. H. Schwitter and S. Bortenschlager. 1983. Accumulation characteristics on a cold, high-Alpine firn saddle from a snow-pit study on Colle Gnifetti, Monte Rosa, Swiss Alps. 7. Glaciol., 29(102), 260-271.

Haeberli, W., W. Schmid and D. Wagenbach. 1988. On the geometry, flow and age of firn and ice at the Colle Gnifetti core drilling site (Monte Rosa, Swiss Alps). Z. Gletscherkd. Glazialgeol., 24(1), 1-19.

Haefeli, R. and F. Brentani. 1955. Observations in a cold ice cap. Part I. F. Glaciol., 2(18), 571-581.

Hooke, R. LeB., J. E. Gould and J. Brzozowski. 1983. Near-surface temperatures near and below the equilibrium line on polar and subpolar glaciers. Z. Gletscherkd. Glazialgeol., 19(1), 1-25.

Lachenbruch, A. H. and M. C. Brewer. 1959. Dissipation of the temperature effect of drilling a well in Arctic Alaska. U.S. Geol. Surv. Bull. 1083-C, 73-109.

Laternser, M. 1992. Firntemperaturemessungen in den Schweizer Alpen. (Diplomarbeit, Eidgenössische Technische Hochschule Zürich. Versuchsanstalt für Wasserbau Hydrologie und Glaziologie.

Lliboutry, L., M. Briat, M. Creseveur and M. Pourchet. 1976. $15 \mathrm{~m}$ deep temperatures in the glaciers of Mont Blanc (French Alps). F. Glaciol., 16 (74), 197-203.

Lüthi, M. 1999. Rheology of cold firn and dynamics of a polythermal ice stream: studies on Colle Gnifetti and Jakobshavns Isbræ. Eidg. Tech. Hochschule, Zürich.Versuchsanst.Wasserbau, Hydrol. Glaziol. Mitt. 165.

Lüthi, M. and M. Funk. 1997. Wie stabil ist der Hängegletscher am Eiger? Spektrum der Wiss., May 1997, 21-24.

Moore, I., T. Norton and J. Williams. 1993a. Modelling environmental heterogeneity in forested landscapes. 7. Hydrol., 150, 717-747.

Moore, I., J. Gallant and L. Guerra. 1993b. Modelling the spatial variability of hydrological processes using GIS. International Association of Hydrological Sciences Publication 211 (Symposium at Vienna 1993-Application of Geographic Information Systems in Hydrology and Water Resources Management), 161-169.

Oeschger, H., U. Schotterer, B. Stauffer, W. Haeberli and H. Röthlisberger. 1978. First results from Alpine core drilling projects. Z. Gletscherkd. Glazialgeol., 13(1-2), 1977, 193-208.

Shumskii, P. A. 1964. Principles of structural glaciology. New York, Dover Publications.

Suter, S. 1995. Die Verbreitung kalter Firn- und Eisregionen im Alpengebiet. (Diplomarbeit, Eidgenössische Technische Hochschule Zürich.)

Suter, S., M. Laternser, W. Haeberli, R. Frauenfelder and M. Hoelzle. 2001. Cold firn and ice of high-altitude glaciers in the Alps: measurements and distribution modelling. F. Glaciol., 47(156), 85-96.

Vallot, J. 1893. Recherche scientifique dans le tunnel du Mont-Blanc. Ann. Observ. Météorol. Phys. Glac. Mont-Blanc, 1, 131-143.

Vallot, J. 1913. Valeur et variation de la température profonde du glacier, au Mont-Blanc. C. R. Hebd. Séances Acad. Sci. (Paris), 156(20), 1575-1578.

Vincent, C., M. Vallon, J. F. Pinglot, M. Funk and L. Reynaud. 1997. Snow accumulation and ice flow at Dôme du Goûter (4300 m), Mont Blanc, French Alps. F. Glaciol., 43(145), 513-521. (Erratum: 44(146), 1998, p. 194.)

Zotikov, I. A. 1986. The thermophysics of glaciers (Teplofizika lednikovykh pokrovov). Dordrecht, etc., D. Reidel Publishing Co. 